DOI: $10.17747 /$ TEDS-2020-22-27

Mikhail V. Zharikov

World Finance Department

Financial University under the Government of the Russian Federation

Moscow, Russia michaelzharikoff@gmail.com

\title{
THE MODEL OF THE BRICS' SHARED INTEREST RATE TO CIRCULATE A DIGITAL CURRENCY
}

\begin{abstract}
The purpose is to offer an approach to introducing a market interest rate to circulate a digital currency in the BRICS. The topic is time-relevant, since economics today faces difficult challenges posed by questions about price stability, future growth and money market equilibrium. A digital currency is a special issue today due to the outbreak of covid-19, which made many central banks think about contactless means of payment. The author revealed policy tools to circulate a hypothetical digital currency in the BRICS, needed for the pentalateral use. The theoretical significance is to lay the foundation for a model that can be used to set up a virtual regional money market for the BRICS. In practical terms the article recommends a set of policy decisions to overcome the coronavirus crisis of 2020.
\end{abstract}

Keywords - BRICS; digital currency; virtual money market; shared interest rate; liberal and gradualist approaches; credit surplus; digital money revenue

\section{INTRODUCTION}

The BRICS celebrates its 20th anniversary in 2021. It is clear by now that unlike the European Union or Eurasian Economic Union, the BRICS is not an integration agreement [1]. The integration process of the BRICS is quite difficult to accomplish due to territorial, cultural, political and economic differences of the member states. However, in the past two decades we can find a few multilateral efforts on part of the member states aimed at deeper trade and cooperation [2].

Things got even more difficult after the outbreak of covid19 in 2020. The coronavirus crisis which followed became a sort of a litmus paper to test the penta-lateral cooperation within the BRICS. The hope is that the BRICS will get out of the crisis stronger. A new period of the BRICS cooperation will bring potential benefits and opportunities for the member states as well as for the countries in close proximity. One of those opportunities may well become the digitization of the trade settlement deals in the BRICS and related countries of the region to bypass the US dollar [3].

In this respect, this paper has a purpose to explain the need to create a model of a shared interest rate of the BRICS as a regional mechanism to finance multilateral development with an optimal cost of capital for the countries of the region.

To meet their needs in new loans for development on better terms compared to the international financial institutions, such as the IMF and the World Bank, the BRICS and the countries of the region can potentially create a virtual regional multilateral money market with an equilibrium interest rate [4].

\section{METHODS}

The optimal equilibrium interest rate can be determined on the conventional idea based on the money supply and the demand for money for the members of the BRICS and other countries of the region. Graphically, this can be expressed in a chart displaying two curves representing the money supply and the demand for money on the shared money market of the BRICS that may emerge in the future. The underlying research proposes a ten-year plan to achieve that by 2030 if all goes well. This market may simultaneously become the market for a new digital currency of the BRICS. As is well-known, the curves of the supply and demand intersect at a point that demonstrates the level of an interest rate at which the central bank acquires IOUs. In central bank operations, there are shortterm, mid-term and long-term rates, generally known as the rates of refinancing. According 
to the neoclassic economics, the graph of supply of and demand for some good, including money, is to do with the curves only in the short term. Therefore, this paper attempts to build the shortterm shared interest rate for the BRICS and other countries of the region.

To simplify the model, which is being constructed here, the research supposes that the supply of money on the potential virtual multilateral market of the BRICS digital currency in the short run must take shape of a vertical line. This is motivated by the fact that the supply of money can potentially be absolutely inelastic and be determined depending on the character of a shared or consensual monetary policy. In turn, the demand for money will intersect with the curve of money supply at a point which will reflect the shared interest rate for the BRICS. This rate will be higher in comparison with the rate of the People's Bank of China at whose expense the supply of money is supposed to be provided as this paper recommends.

\section{DISCUSSION}

Since the countries with the world reserve currencies usually pursue loose monetary policy [5], a central monetary authority of the BRICS will also have to do that. The central monetary authority will have to expand the money supply of the BRICS digital currency in case of an increase in the demand for it on the hypothetical virtual money market. As a result, the local inter-bank offer rates in the high-interest-rate members of the BRICS will decrease, and the money supply and the demand for the digital currency will be set at a new equilibrium level which will be optimal for them [6].

Once the shared interest rate is established on the BRICS hypothetical virtual money market, the member states of the BRICS will be faced with a problem of having to adjust their local rates of refinancing. According to the hypothesis introduced in the research, Brazil will have to do with the biggest drop in its local rate of refinancing, because in 2016-2019 there was the highest rate of refinancing in the BRICS there. In case of China, the rate of refinancing is going to be set at a level a bit higher compared to the domestic rate in China.

\section{A. THE LIBERAL MODEL OF THE SHARED INTEREST RATE FOR THE BRICS}

The liberal model of price building was originally supposed to be used for the world market of goods such as grain, crude oil, natural gas, etc. These commodities are usually traded at world prices. This paper proposes that this model be used also to determine the shared interest rate for the BRICS. This is done because generally an interest rate is the price of money at which commercial banks get loans from a central bank. This model is applicable for the purpose, since it poses no constraints for cross-border transactions. And since the world money market is a virtual place which works in total absence of any barriers, the liberal model is going to be the optimal mechanism to set up the shared interest rate for the BRICS [7].

The curves of domestic supply and demand for the hypothetical digital currency of the BRICS are formed depending on the loan rates of the major commercial banks and local supply of money which were used to determine the level of the shared interest rate. To simplify the model of the shared interest rate for the BRICS, a trend line should be drawn which flattens the deviations of the loan rates set by individual commercial banks. The equations of trend lines for each member state of the BRICS are found in Table 1. In the BRICS the money demand curve is least elastic in Brazil, and it is most elastic in China. In turn, India and South Africa have elasticities of demand for money a bit larger than in Russia. 
TABLE I. DIGITAL MONEY DEMAND CURVE EQUATIONS IN THE BRICS

\begin{tabular}{|l|l|}
\hline \multicolumn{1}{|c|}{ BRICS } & \multicolumn{1}{c|}{ The equations of digital money demand } \\
\hline Brazil & $\mathrm{y}=-0,26174 \mathrm{x}+31,17764$ \\
\hline Russia & $\mathrm{y}=-0,09324 \mathrm{x}+21,74156$ \\
\hline India & $\mathrm{y}=-0,04007 \mathrm{x}+11,42709$ \\
\hline China & $\mathrm{y}=-0,000891266 \mathrm{x}+3,905214846$ \\
\hline South Africa & $\mathrm{y}=-0,77467 \mathrm{x}+14,85721$ \\
\hline BRICS & $\mathrm{y}=-1,9115 \mathrm{x}+12,47$ \\
\hline
\end{tabular}

Source: author's calculations based on the official financial statements of commercial banks from the BRICS.

\section{B. THE GRADUALIST MODEL OF THE SHARED INTEREST RATE FOR THE BRICS}

Since the liberal model of the shared interest rate for the BRICS implies no constraints, the loans provided through the described mechanism ought to be consumed in one year's time. It means that Brazil, Russia, India and South Africa are to consume virtually all credit provided by China at the moment the loans are granted. Such quick consumption of loaned money in Greece, for example, when the euro had first been introduced, led to the outbreak of the debt crisis in the country and later to a technical default [8].

Contrary to that, if the shared interest rate for the BRICS were to be set up step-by-step, over several years according to the gradualist approach, it would have reached the level of rR2, or $2 \%$, in correspondence with the model built, and the respective volumes of additional external loans provided by China would have increased to 44.7 billion dollars in Brazil,

83.7 billion dollars in Russia, 118.1 billion dollars in India and

6.4 billion dollars in South Africa (Fig. 1).

Fig. 1. Gradualist model of the shared interest for the BRICS

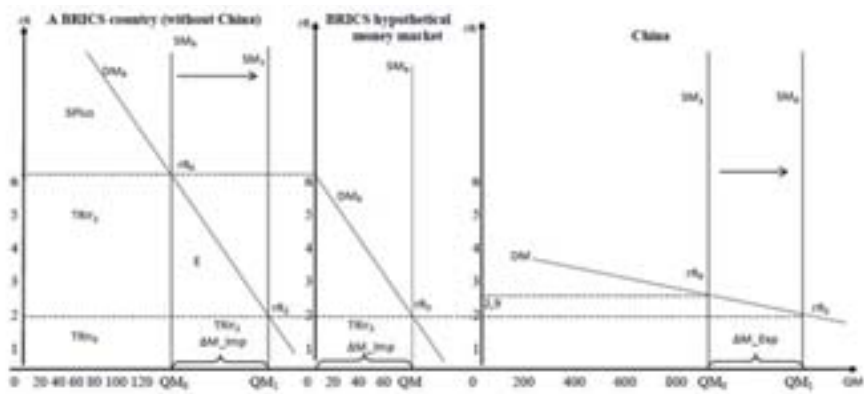

These volumes contrary to the liberal model would have then been allocated relatively evenly over the entire period of monetary and financial harmonization of the BRICS, which would have been less painful for them, and this would have allowed them to gradually adapt to the transformation of the national monetary systems and their consequent joining the common monetary system. At the same time, the credit surpluses in each of the BRICS would have also increased gradually: in Brazil - by 16.9 billion dollars, in Russia - by 21 billion dollars, in India - by 13.9 billion dollars and South Africa - by 1.1 billion dollars, without causing consumer boom, although these volumes would have exceeded the credit surpluses received by Brazil, Russia, India and South Africa as a result of forced liberalization. 
The cumulative loans provided to Brazil, Russia, India and South Africa according to the gradualist model built would have amounted to 253 billion dollars by 2030 , which also just like in case of the liberal model would have significantly exceeded the capacity of the BRICS Development Bank.

A next stage of the calculations is supposed to determine the cumulative volume of loans provided at the shared interest rate for the BRICS as a single entity. The initial hypothesis about the shared money market for the BRICS and the shared interest rate supposed that its level could have settled at a level, unfavorable for China and significantly higher than the initial rate. However, the resulting shared interest rate for the BRICS distinguishes from the initial equilibrium of the national monetary system in China by only $0.05 \%$. Nevertheless, the increase in the local loan rate in China by this small amount, according to the model built, would have led to a decrease in the quantity of money in that country's economy circulation by 55.3 billion dollars.

In turn, the money loaned out at the new shared rate of interest for the BRICS as a single entity at $2 \%$ in accordance with the gradualist model is going to have a deeper impact on the respective national economies than as a result of decreasing domestic rates at the initial stage of the calculations, i.e. based on the liberal model. Thus, in addition to the initial supply of money loaned, the money in circulation would have increased to 111.2 billion dollars in Brazil, 209.7 billion dollars in Russia, 234.9 billion dollars in India and 16.6 billion dollars in South Africa without the printing presses. The cumulative influx of the money loaned out to these four countries would have been equal to 253 billion dollars.

The outflow of capital from China at the $2 \%$ interest rate would have exceeded 1 trillion dollars. It means China could in fact have generated additional money supply for other countries of the region to the amount of almost 772 billion dollars loaned out in the new shared digital currency of the BRICS. Thus, the equilibrium of the monetary system of the BRICS based on the liberal model of the shared interest rate could have been achieved by injecting 217 billion dollars. The gradualist model could have done that by injecting 253 billion dollars. Hence, the resulting equilibrium differs from the initial one in the liberal model by almost 40 billion dollars.

The liberal and gradualist models built by the author to determine the shared interest rate exhibit the hypothetical money market equilibrium, namely the amount of credit exported from China must equal to the amount of capital received by Brazil, Russia, India and South Africa, i.e. the influx of capital to Brazil, Russia, India and South Africa and the outflow of capital from China are one and the same figure. Alongside this, when the needs of Brazil, Russia, India and South Africa in loans exceed their initial capacity, China would have to create additional supply of money expressed in the new digital currency at the shared interest rate both for the hypothetical money market and for other countries' purposes.

If there were no equilibrium, this would have meant an error in the model built. The point is that if in the course of calculating loan rates for Brazil, Russia, India and South Africa it turned out that more loans could be provided at them in Brazil than in India, for example, although according to the law of demand it must be vice versa since the demand elasticity for money in the latter were bigger than in the former, then it might be caused by a statistical error in the calculations conducted. Therefore, since the loan rate is determined for each of the BRICS on an individual basis with regard to the potential needs in loans and the capacity of a country to efficiently absorb them with no implications such as high inflation, it is necessary to introduce respective adjustments to the model built.

First of all, the liberal model of the shared interest rate for the BRICS did take into account that on the hypothetical shared money market the curves of supply and demand might alter their elasticity. At this point the rate itself might not change, but what was necessarily going to change was the quantity of money provided as loans. It must either increase or decrease. If this is true, it is critical to step back to the stage of determining the rates and the volume of new digital money supply on the charts representing Brazil, Russia, India and South Africa and make adjustments for 
the amount of money supplied, this time taking into consideration a principle according to which the higher the shared interest rate, the less is the amount of credit and vice versa.

Secondly, since the shared interest rate is formed on the hypothetical digital money of the BRICS, it is important to exclude a possibility of an error in the amount of the interest rate in general since the use of the same equations in each of the cases is going to produce a universal system of functions, and it will end in the universal methodology and a common approach to carrying out the calculations. As to the possibility of an arithmetic error, the model still stays true even at this point, because the amount of loans made in the economy is directly dependent on its capacity to wholly and efficiently absorb the money loaned out. Oversupply of loans, in turn, may lead to hypertrophied expenditure by households, manufacturing firms and the economy at large. It may also cause a credit boom, overheat and an eventual sharp recession.

But since the liberal model was initially used to set the rates, it supposes no restrictions. Therefore, the amount of money loaned out cannot be constrained by anything. Hence, the demand for loans on part of the BRICS at the shared interest rate does not change. What changes is the amount of loans made at that rate. Hence, it is important to adjust the elasticity of the respective curves. As a result of referring the new curve of the demand for loans to the curve of money supply on the shared market of the BRICS, there emerges the required shared rate of refinancing for the BRICS as a single entity.

\section{RESULTS}

A final stage of building the model of the shared interest rate for the BRICS is to estimate the implications of introducing the new rate for the banking sectors of the BRICS. Achieving such a result could be especially significant, for the member states of the BRICS when looking for ways aimed at helping economic recovery after the coronavirus crisis of 2020.

Based on the research, the following outcomes can be delivered:

- The article offers a very cautious gradualist approach in dealing with a hypothetical digital currency for the BRICS, based on a virtual platform that can be used by the countries of the related region.

- The system of digital money circulation in the economies of the region is not perfect. However, it continually improves and, most importantly, in the region today there is no more effectively working alternative than the monetary system based on a digital currency.

- The international division of labor, the internationalization of capital, production and labor exist only if there is highly developed money circulation. The modern architecture of money circulation and money itself gave birth to a human being of today and the organization of human labor on a highly intellectual level. In the end, technological change and industrial revolution would be impossible without such trade and dealings in digital money, cryptocurrencies and other quasi money.

- Since the overwhelming majority of assets in the world are expressed in US dollars, the introduction of the new digital currency for the BRICS and other countries of the region will hardly influence the world market.

- The research revealed the significance of the most important macroeconomic indicators which characterize the hypothetical digital money market of the BRICS, namely, a shared interest rate and the quantity of digital money in circulation needed for the penta-lateral use as well as for the use of the countries in close proximity.

\section{ACKNOWLEDGMENT}

The article was written with financial support of the Russian federal budget according to the assignment given to the Financial University. 


\section{REFERENCES}

[1] R. Beetsma, M. Giuliodori, F. De Jong, and D. Widijanto, "Price effects of sovereign debt auctions in the euro-zone: the role of the crisis," Journal of Financial Intermediation, no 25, pp. 30-53, 2016.

[2] D. Boddin, and F. Stähler, "The organization of international trade," CESifo Working Paper, no. 7378, pp. 6-10, 2018.

[3] Y.(G.) Hou, and S. Li, "Volatility and skewness spillover between stock index and stock index futures markets during a crash period: new evidence from China," International Review of Economics \& Finance, vol. 3, no. 66, pp. 166-188, 2020. DOI: 10.1016/j. iref.2019.11.003

[4] T. Jain, S. Sehgal, and R. Agrawal, "Disruptive innovations, fundamental strength and stock winners: implications for stock index revisions," Vision-The Journal of Business Perspective, vol. 3, no. 24, pp. 356-370, 2020. DOI: 10.1177/0972262920928890

[5] K. Khan, H.W. Zhao, H. Zhang, H.L. Yang, M. Haroon, and A. Jahanger, "The impact of covid-19 pandemic on stock markets: an empirical analysis of world major stock indices," Journal of Asian Finance Economics and Business, vol. 7, no. 7, pp. 463-474, 2020. DOI: 10.13106/jafeb.2020.vol7.no7.463

[6] A.A. Salisu, and L.O. Akanni, "Constructing a global fear index for the covid-19 pandemic," Emerging Markets Finance and Trade, vol. 10, no. 56, pp. 2310-2331, 2020. DOI: 10.1080/1540496X.2020.1785424

[7] M. Younsi, and M. Bechtini, "Economic growth, financial development, and income inequality in BRICS countries: does Kuznets' inverted ushaped curve exist?" Journal of the Knowledge Economy, vol. 2, no. 11, pp. 721-742, 2020. DOI 10.1007/s13132-018-0569-2

[8] P. Zou, Q. Wang, J.H. Xie, and C.X. Zhou, "Does doing good lead to doing better in emerging markets? Stock market responses to the SRI index announcements in Brazil, China, and South Africa," Journal of the Academy of Marketing Science, vol. 5, no. 48, pp. 966-986, 2020. DOI: 10.1007/s11747-019-00651-z 